\title{
Superior antitumoral activity of dimerized targeted single-chain TRAIL fusion proteins under retention of tumor selectivity
}

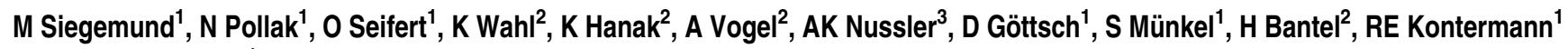 \\ and $K$ Pfizenmaier ${ }^{*}, 1$
}

\begin{abstract}
Although targeting of the death receptors (DRs) DR4 and DR5 still appears a suitable antitumoral strategy, the limited clinical responses to recombinant soluble TNF-related apoptosis inducing ligand (TRAIL) necessitate novel reagents with improved apoptotic activity/tumor selectivity. Apoptosis induction by a single-chain TRAIL (scTRAIL) molecule could be enhanced $>10$-fold by generation of epidermal growth factor receptor (EGFR)-specific scFv-scTRAIL fusion proteins. By forcing dimerization of ScFv-scTRAIL based on scFv linker modification, we obtained a targeted scTRAIL composed predominantly of dimers (Db-scTRAIL), exceeding the activity of nontargeted scTRAIL 100-fold on Huh-7 hepatocellular and Colo205 colon carcinoma cells. Increased activity of Db-scTRAIL was also demonstrated on target-negative cells, suggesting that, in addition to targeting, oligomerization equivalent to an at least dimeric assembly of standard TRAIL per se enhances apoptosis signaling. In the presence of apoptosis sensitizers, such as the proteasomal inhibitor bortezomib, Db-scTRAIL was effective at picomolar concentrations in vitro $\left(\mathrm{EC}_{50} \sim 2 \times 10^{-12} \mathrm{M}\right)$. Importantly, in vivo, Db-scTRAIL was well tolerated and displayed superior antitumoral activity in mouse xenograft (Colo205) tumor models. Our results show that both targeting and controlled dimerization of scTRAIL fusion proteins provides a strategy to enforce apoptosis induction, together with retained tumor selectivity and good in vivo tolerance.
\end{abstract}

Cell Death and Disease (2012) 3, e295; doi:10.1038/cddis.2012.29; published online 12 April 2012

Subject Category: Experimental Medicine

The TNF-related apoptosis-inducing ligand (TRAIL; Apo2L/ Dulanermin) as well as TRAIL-agonistic antibodies are able to kill a broad range of tumor cell lines in vitro, are well tolerated in vivo and thus applicable for therapy of cancer. ${ }^{1,2}$ Nonetheless, clinical trials revealed that the use of soluble, recombinant TRAIL, given alone or in combination with other drugs, may be often insufficient to gain significant therapeutic effects. For example, in a phase II trial focusing on treatment of patients with relapsed follicular non-Hodgkin's lymphoma $(\mathrm{NHL})$, the response rate of the anti-CD20 antibody rituximab was not improved when TRAIL was given in combination. ${ }^{3}$ Accordingly, the improvement of TRAIL-based therapies should address the apparent shortcomings of present TRAIL reagents, namely short in vivo half-life and low specific bioactivity. In addition, sensitization of tumor cells toward the apoptosis-inducing activity of TRAIL appears particularly relevant.
Resistance to TRAIL-induced apoptosis can be caused by the expression levels and composition of proapoptotic and decoy TRAIL receptors as well as by intracellular mechanisms. The cell surface expression of death receptor (DR) 4 or DR5 is a prerequisite for TRAIL-mediated apoptosis, but is insufficient in case of blocked intracellular pathways. Levels of inhibitor of apoptosis proteins, such as X-linked inhibitor of apoptosis protein (XIAP), have been shown to be critical determinants of TRAIL sensitivity in melanoma. ${ }^{4}$ In hepatocellular carcinoma (HCC), several factors including the decreased expression of CD95 (Apo1/Fas) ${ }^{5}$ activation of transcription factor nuclear factor- $\kappa \mathrm{B}(\mathrm{NF}-\kappa \mathrm{B})^{6}$ or overexpression of pro-inflammatory cytokines and their receptors ${ }^{7}$ accompany such dysregulation of apoptotic signaling. However, TRAIL has been shown to induce cell death selectively in HCC when tumor cells are sensitized by chemotherapeutics like the multi-kinase inhibitor sorafenib ${ }^{8}$ and the proteasome

\footnotetext{
${ }^{1}$ Institute of Cell Biology and Immunology, University of Stuttgart, Allmandring 31, D-70569 Stuttgart, Germany; ${ }^{2}$ Department of Gastroenterology, Hepatology and Endocrinology, Hannover Medical School, Carl-Neuberg-Str. 1, D-30625 Hannover, Germany and ${ }^{3}$ Department of Trauma Surgery, Eberhard Karls University Tübingen, Schnarrenbergstr. 95, D-72076 Tübingen, Germany

${ }^{*}$ Corresponding author: K Pfizenmaier, Institute of Cell Biology and Immunology, University of Stuttgart, Allmandring 31, D-70569 Stuttgart, Germany.

Tel: + 497116856 6986; Fax: + 497116856 7484; E-mail: klaus.pfizenmaier@izi.uni-stuttgart.de

Keywords: Apo2L; TRAIL oligomers; EGFR-targeting; apoptosis; scFv

Abbreviations: Ac-DMQD-AMC, Ac-Asp-Met-Gln-Asp-7-Amino-4-methylcoumarin; ALT, alanine aminotransaminase; CHX, cycloheximide; DR, death receptor; ECL, enhanced chemoluminescence; EGFR, epidermal growth factor receptor; Fab, antigen-binding fragment; FCS, fetal calf serum; FITC, fluorescein isothiocyanate; GAPDH, glyceraldehyde 3-phosphate dehydrogenase; HCC, hepatocellular carcinoma; HRP, horseradish peroxidase; IMAC, immobilized metal affinity chromatography; i.p., intraperitoneal(Iy); MTT, 3-(4,5-dimethylthiazol-2-yl)-2,5-diphenyltetrazolium bromide; NF- $\kappa$ B, nuclear factor- $\kappa$ B; NHL, non-Hodgkin's lymphoma; NSCLC, non-small cell lung cancer; PHH, primary human hepatocyte; RTK, receptor tyrosine kinase; s.c., subcutaneous(ly); scFv, single-chain Fv fragment; scTRAIL, single-chain TRAIL; TNF, tumor necrosis factor; TRAIL, TNF-related apoptosis-inducing ligand; TRAILR, TRAIL receptor; $\mathrm{V}_{\mathrm{H}}$, variable domain of immunoglobulin heavy chain; $V_{L}$, variable domain of immunoglobulin light chain; XIAP, X-linked inhibitor of apoptosis protein; zDEVDfmk, z-Asp-Glu-Val-Asp-fluoromethylketone; zVADfmk, z-Val-Ala-Asp-fluoromethylketone
}

Received 18.11.11; revised 20.2.12; accepted 21.2.12; Edited by A Stephanou 
inhibitor bortezomib. ${ }^{9,10}$ The clinical relevance of TRAIL receptor (TRAILR)-directed therapy of HCC is emphasized by current studies ${ }^{11}$ (see also http://clinicaltrials.gov/ct2/ show/study/NCT01258608).

Different approaches have been taken to enhance specific apoptotic activity and maintain high tumor selectivity of recombinant TRAIL molecules. Thus, TRAIL mutants, acting predominantly on either DR4 or DR5, facilitate cell death induction, for example on DR5-positive tumor cells, without the need for membrane immobilization or crosslinking of soluble TRAIL. ${ }^{12,13}$ Alternatively, TRAIL can be fused to antibodies directed against tumor markers. It has been shown for CD33-directed scFv-TRAIL that such fusion proteins are superior over antibody-targeted chemotherapeutics because of stronger cytotoxic activity and the minimization of side effects on normal nontransformed cells. ${ }^{14}$ Correct trimerization and zinc coordination of recombinant TRAIL therapeutics seem to be crucial for biological activity and for nonreactivity toward nontransformed cells, in particular hepatocytes. ${ }^{15}$ Our previous results showed that three extracellular domains of human TRAIL can be fused by peptide linkers to yield highly active single-chain TRAIL (ScTRAIL) that can be further endowed with target-dependent activity by fusion to an antibody derivative. ${ }^{16}$ Such antigen-binding scFv-scTRAIL molecules functionally mimic the natural membraneexpressed TRAIL and are more effective therapeutics than scTRAIL alone. ${ }^{16}$ We here sought to develop a concept for controlled oligomerization of ScFv-scTRAIL fusion proteins leading to improved expression and stability as well as increased functional activity under retention of tumor selectivity.

\section{Results}

Construction and preparation of scTRAIL fusion proteins. For generation of functionally improved scFvSCTRAIL fusion proteins, scTRAIL was first genetically optimized for mammalian expression. Additionally, the linker motifs in the molecule were reduced from (GGGS) to $(\mathrm{GGGS})_{2}$, potentially making the protein more rigid and less prone to aggregation without affecting apoptosis induction (data not shown).

In this study, we used epidermal growth factor receptor (EGFR), an established tumor marker overexpressed in several carcinomas, including colon, lung and liver cancer, ${ }^{17}$ as a model for targeting. The chimeric monoclonal antibody cetuximab (C225) is directed against the extracellular domain of EGFR and blocks receptor activation by interfering with ligand binding. ${ }^{18}$ This antibody was approved for treatment of advanced metastatic colorectal cancer, squamous cell carcinoma of the head and neck, and is evaluated in non-small cell lung cancer (NSCLC). ${ }^{19,20} \mathrm{~A}$ humanized single-chain Fv fragment (scFv) 'huC225' (RE Kontermann, unpublished data) derived from cetuximab was fused to the $\mathrm{N}$-terminus of ScTRAIL, yielding $s c F v_{\alpha E G F R}-s c T R A I L$ (Figure 1a). The aim of this work was the improvement of the proapoptotic activity of $\mathrm{SCFv}_{\alpha \mathrm{EGFR}}$-ScTRAIL fusion proteins under retention of tumor selectivity, that is, nonreactivity toward normal, nonmalignant tissue. TRAIL bioactivity depends on the oligomerization state, in particular relevant for TRAILR2 (DR5), which is poorly activated by soluble, trimeric forms of TRAIL. ${ }^{21,22}$ As DR5 appears to be the major mediator of apoptosis signaling in the vast majority of carcinoma cells, we reasoned that a dimeric variant of $S c F v_{\alpha E G F R}$-ScTRAIL should combine tumor targeting with an even more enhanced DR5 activation. Dimerization was accomplished by reducing the linker between $V_{H}$ (variable domain of immunoglobulin heavy chain) and $V_{L}$ (variable domain of immunoglobulin light chain) from (GGGGS) $)_{3}$ to GGGGS as described for the so-called diabodies, ${ }^{23}$ yielding $\mathrm{Db}_{\alpha \mathrm{EGFR}}$-SCTRAIL.

ScFV $v_{\alpha E G F R}$-ScTRAIL and $\mathrm{Db}_{\alpha \mathrm{EGFR}}$-ScTRAIL were produced and purified with yields of $>3 \mathrm{mg}$ highly pure protein per liter cell culture supernatant. SDS-PAGE and immunoblotting revealed single bands with molecular masses of $\sim 70 \mathrm{kDa}$ for ScTRAIL and $\sim 100 \mathrm{kDa}$ for $\mathrm{SCFv}_{\alpha \mathrm{EGFR}}$-SCTRAIL and $\mathrm{Db}_{\alpha \mathrm{EGFR}}$-ScTRAIL, matching the calculated values of 68 and $94 \mathrm{kDa}\left(93 \mathrm{kDa}\right.$ for $\mathrm{Db}_{\alpha \mathrm{EGFR}}$-SCTRAIL), respectively (Figure 1b). The size exclusion chromatography of ScTRAIL and $\mathrm{ScFv} \mathrm{V}_{\alpha \mathrm{EGFR}}$-ScTRAIL (Figure 1c) indicated a monomeric composition for the majority of the protein (>94\%). Interestingly, $\mathrm{Db}_{\alpha \mathrm{EGFR}}$-ScTRAIL was present in a heterogeneous state with a major peak corresponding to the expected dimer and a minor peak representing putative trimers or tetramers. Upon separation of both isoforms, equal amounts of the higher-order isoforms and the dimer displayed in vitro identical bioactivity (data not shown) indicating that higher than dimeric forms of scTRAIL oligomers apparently do not further enhance apoptosis signaling.

EGFR-specific binding of scTRAIL fusion proteins. The specific binding of SCTRAIL fusion proteins to EGF receptors was analyzed by flow cytometry of Huh-7 cells, displaying moderate EGFR expression compared with HepG2 cells with barely detectable EGFR (Supplementary Figure S1). $\mathrm{SCFV}_{\alpha \mathrm{EGFR}}$-SCTRAIL and $\mathrm{Db}_{\alpha \mathrm{EGFR}}$-SCTRAIL binding was detectable on Huh-7 and HepG2 cells, but competition of fusion protein binding by preincubation of cells with the anti-EGFR scFv huC225 $(2 \mu \mathrm{M})$ was only possible on Huh-7 cells (Figure 2a). Moreover, Huh-7 cell binding of Alexa 488 (Life Technologies, Darmstadt, Germany) labeled EGFRspecific cetuximab was blocked by preincubation with $0.5 \mu \mathrm{M}$ $\mathrm{Db}_{\alpha \mathrm{EGFR}}$-ScTRAIL (Figure 2b). The intermediate fluorescence signal observed upon competition of fusion protein binding on Huh-7 cells likely reflects the binding of the scTRAIL moiety to TRAIL receptors and is consistent with the low but specific signal obtained from scFv $v_{\alpha E G F R}$-scTRAIL and $\mathrm{Db}_{\alpha \mathrm{EGFR}}$-ScTRAIL binding to TRAILR ${ }^{+}$EGFR $^{-}$HepG2 cells. Binding competition of both fusion proteins with EGFR-specific antibody/ scFv on EGFR ${ }^{+}$cells is evidence for the structural integrity and functionality of the ScFv and diabody targeting modules of the fusion proteins.

Quantitative binding studies of ScTRAIL fusion proteins to $\mathrm{EGFR}^{+}, \mathrm{DR}^{+}{ }^{+} \mathrm{DR} 5^{+} \mathrm{NCl}-\mathrm{H} 460$ cells revealed significantly different $(P=0.003) \quad \mathrm{EC}_{50}$ values for $\mathrm{scFv}_{\alpha \mathrm{EGFR}}$ SCTRAIL $\left(3.6 \pm 0.3 \times 10^{-10} \mathrm{M}\right)$ and $\mathrm{Db}_{\alpha \mathrm{EGFR}^{-S C T R A I L}}$ $\left(1.6 \pm 0.3 \times 10^{-10} \mathrm{M}\right)$, implicating an avidity effect of the specific molecular composition of the divalent $\mathrm{Db}_{\alpha \mathrm{EGFR}}$ SCTRAIL and therefore potentially superior targeting compared with $S C F v_{\alpha E G F R}$-ScTRAIL (Figure 2c). To investigate whether 
a

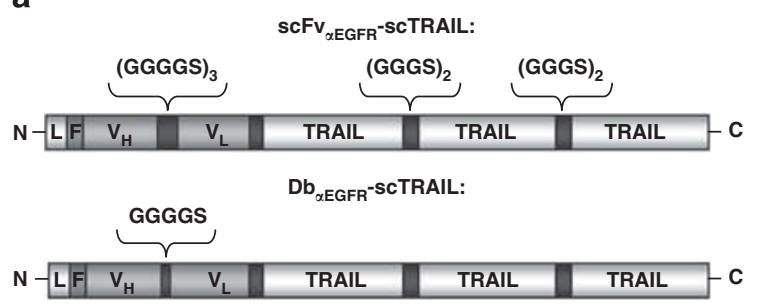

b

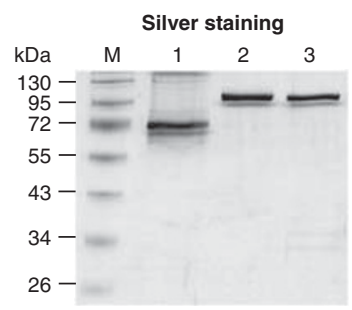

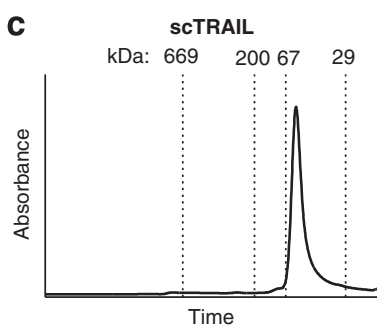
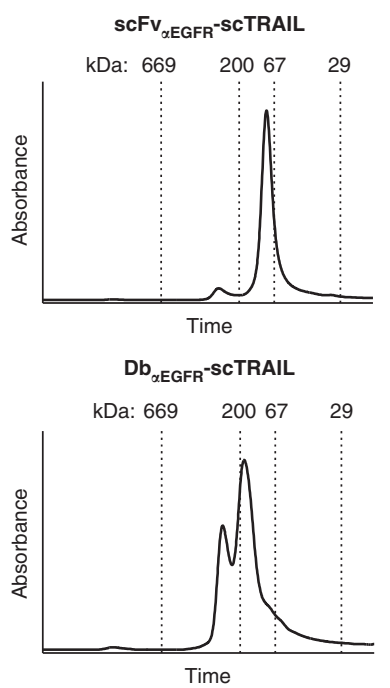

Figure 1 Biochemical analysis of ScTRAIL and scTRAIL fusion proteins. (a) Design of novel scTRAIL fusion proteins. Three human TRAIL domains (aa residues 95-281) were fused with $(G G G S)_{2}$ peptide linkers yielding single-chain TRAIL. EGFR-specific scFv antibody fragments comprising $V_{H}$ and $V_{L}$ were fused $N$-terminally to scTRAIL. (GGGGS) $)_{3}$ or GGGGS peptide linkers between $V_{H}$ and $V_{L}$ were chosen to obtain a scFv or a diabody configuration, respectively. $L, V_{H}$ leader; $F$, FLAG tag. (b) Purified

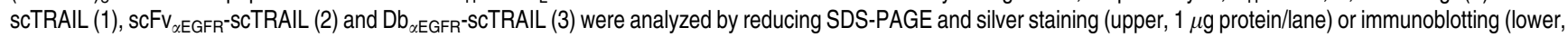
$250 \mathrm{ng}$ protein/lane) against TRAIL or FLAG. (c) scTRAIL and derived fusion proteins were separated by size exclusion chromatography. Thyroglobulin (669 kDa), $\beta$-amylase $(200 \mathrm{kDa})$, bovine serum albumin $(67 \mathrm{kDa})$ and carbonic anhydrase $(29 \mathrm{kDa})$ were used as standard proteins

or not the cetuximab-derived, humanized scFv has retained in its divalent diabody format the functional activity of cetuximab, we checked for blocking of EGF-induced EGFR autophosphorylation by $\mathrm{Db}_{\alpha \mathrm{EGFR}}$-ScTRAIL, whereby cetuximab served as a positive control. Functional blocking of EGFstimulated receptor activation by the divalent $\mathrm{Db}_{\alpha \mathrm{EGFR}}{ }^{-}$ ScTRAIL could be demonstrated for both Colo205 (Figure 2d, left panel) and Huh-7 (Figure 2d, right panel) cells.

Target-independent induction of cell death by ScTRAIL fusion proteins. To investigate the basic bioactivity of ScTRAIL fusion proteins without the influence of targeting domains, we analyzed cell death induction on the targetnegative cell lines HepG2 (hepatoma) and Jurkat (T-cell leukemia) and compared it with scTRAIL devoid of a targeting domain (Table 1 and Figure 3a). On HepG2 cells, $\mathrm{Db}_{\alpha \mathrm{EGFR}}$-ScTRAIL exerted an $\sim 10$-fold increased bioactivity

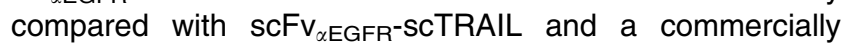
available, highly active 'KillerTRAIL' (Figure 3a, left panel). Because of the EGFR deficiency of HepG2 cells, the proapoptotic activities of $\mathrm{Db}_{\alpha \mathrm{EGFR}}-\mathrm{ScTRAIL}$ and $\mathrm{ScF} \mathrm{v}_{\alpha \mathrm{EGFR}}{ }^{-}$ ScTRAIL were not influenced by the presence of an at least sevenfold excess $(70 \mathrm{nM})$ of the EGFR-blocking cetuximab (not shown). Accordingly, the bioactivity of $\mathrm{scFv}_{\alpha \mathrm{EGFR}}{ }^{-}$ SCTRAIL did not differ from that one of ScTRAIL. On
$\mathrm{EGFR}^{-}, \mathrm{DR}^{-}{ }^{-} \mathrm{DR} 5^{\text {weak }}$ Jurkat cells, which are known to be sensitive for apoptosis induced by TRAIL oligomers, again we found a higher proapoptotic activity of $\mathrm{Db}_{\alpha \mathrm{EGFR}}$-ScTRAIL compared with KillerTRAIL and, as expected, no reactivity toward non-oligomerized $\mathrm{ScFv}_{\alpha \mathrm{EGFR}}$-SCTRAIL or SCTRAIL (Figure $3 a$, right panel), underlining the target-independent higher apoptotic activity of the dimeric scTRAIL fusion protein.

EGFR-directed enhancement of cell death by scTRAIL fusion proteins. The $\mathrm{EGFR}^{+}$human colon carcinoma Colo205 and liver carcinoma Huh-7 were chosen to demonstrate the enhancement in bioactivity achievable by the receptor targeting capacity of $\mathrm{ScFv}_{\alpha \mathrm{EGFR}}$-ScTRAIL and $\mathrm{Db}_{\alpha \mathrm{EGFR}}$-SCTRAIL. Both cell lines require sensitization by either cycloheximide ( $\mathrm{CHX}$ ) or bortezomib to reveal efficient TRAIL-mediated apoptosis induction in vitro (Figure $3 b$ ). Compared with ScTRAIL, the enhancement in bioactivity of the monovalent ScFv $v_{\alpha E G F R}$-ScTRAIL was $\sim 16$-fold on Huh-7 cells and $\sim 6$-fold on Colo205 cells, whereby Colo205 expressed less EGFR compared with Huh-7 (Figure 3b and Supplementary Figure S1). Interference with EGFR binding by co-incubation with an excess of cetuximab ( $70 \mathrm{nM})$ revealed a right shift of the dose-response curve of ScFv $\mathrm{VEGFR}_{\alpha \mathrm{SCTRAIL}}$ toward the $\mathrm{EC}_{50}$ of nontargeted 
a
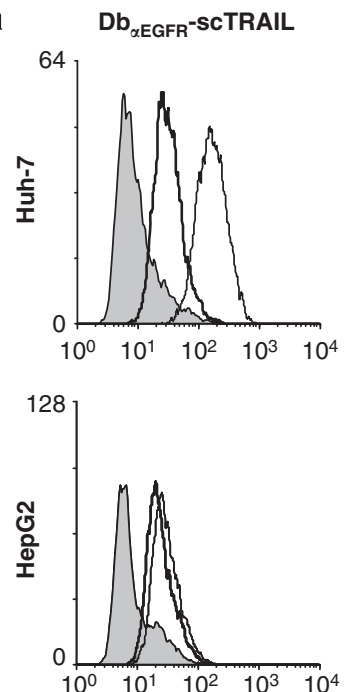

$\square$ Contro

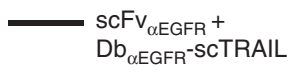

$-\mathrm{Db}_{\alpha \mathrm{EGFR}}{ }^{-\mathrm{SCTRAIL}}$
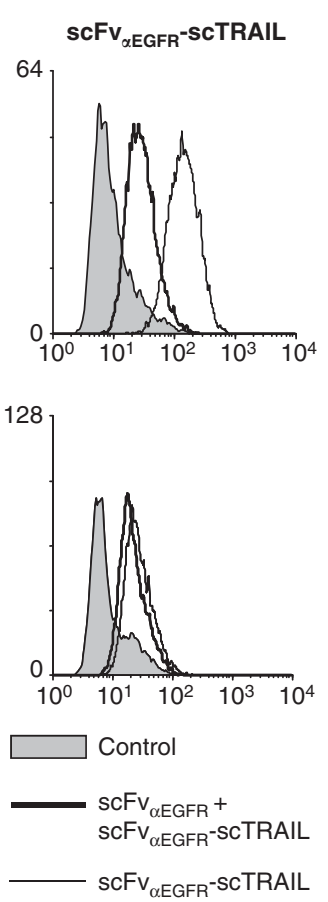

b
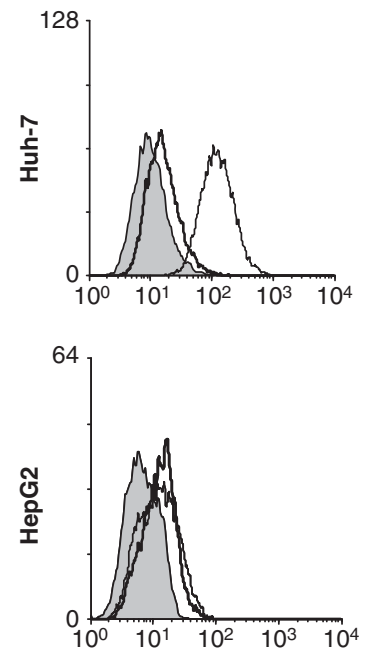

Isotype Control

$\mathrm{Db}_{\alpha \mathrm{EGFR}^{-S C T R A I L}+}$ Cetuximab

C

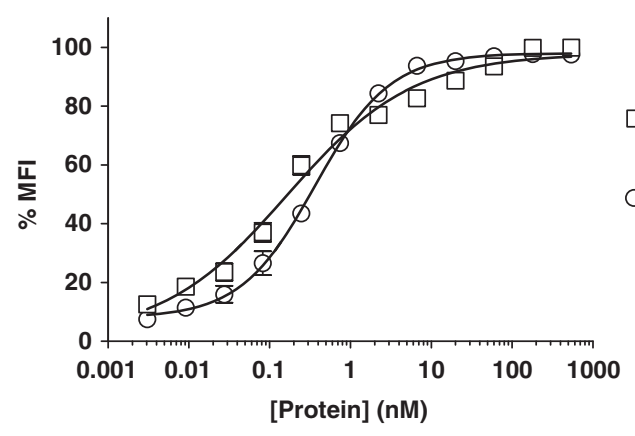

d
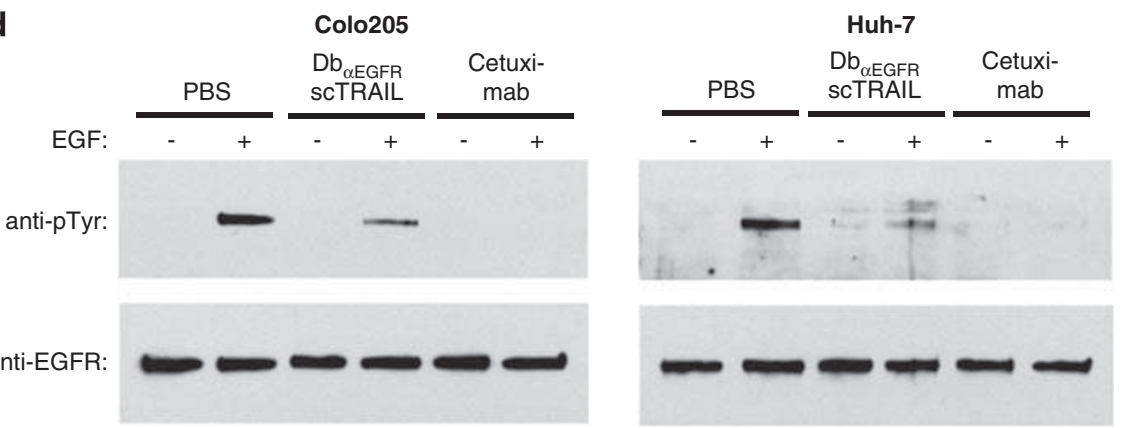

Figure 2 Receptor interaction of EGFR-specific scTRAIL fusion proteins. (a) Binding of $\mathrm{Db}_{\alpha \mathrm{EGFR}}$-ScTRAIL and scFv ${ }_{\alpha E G F R}$-scTRAIL to target-negative HepG2 and targetpositive Huh-7 cells (thin-lined histograms). Furthermore, cells were preincubated with an excess of anti-EGFR scFv before adding scTRAIL fusion proteins (bold histograms). Filled histograms, controls without scTRAIL fusion proteins. (b) Blocking of the binding of Alexa Fluor 488-labeled cetuximab to HepG2 and Huh-7 by an excess of Db ${ }_{\alpha E G F R}{ }^{-}$ scTRAIL (bold histograms). Thin-lined histograms, cetuximab alone; filled histograms, isotype controls. (c) Dose-response relationship of scTRAIL fusion protein binding to $\mathrm{EGFR}^{+} \mathrm{NCl}-\mathrm{H} 460$ cells by indirect immunofluorescence flow cytometry to reveal concentration of half-maximum binding (EC50) (mean \pm S.E.M., $\left.n=4\right)$. (d) Colo205 and Huh-7 cells were serum-starved overnight and then incubated with $2 \mathrm{nM}$ of $\mathrm{Db}_{\alpha \mathrm{EGFR}}$-sCTRAIL, cetuximab and PBS for control, respectively. After $10 \mathrm{~min}, 50 \mathrm{ng} / \mathrm{ml}$ EGF was added and cells were incubated for additional $20 \mathrm{~min}$ followed by cell lysis. EGF receptors were immunoprecipitated using a specific mouse monoclonal antibody and subjected to SDS-PAGE followed by immunoblotting with phosphotyrosine antibody (top). Total amounts of EGFR were determined by reprobing the membrane with EGFR-specific rabbit polyclonal antibody (bottom)

scTRAIL (Table 1), pointing to an improvement of scTRAIL bioactivity by EGFR targeting. $\mathrm{Db}_{\alpha \mathrm{EGFR}}$-SCTRAIL, representing a dimeric assembly of scFv-scTRAIL, showed an $\sim 10$-fold enhanced bioactivity compared with monovalent ScFV ${ }_{\alpha E G F R}$-SCTRAIL and an $\sim 100$-fold enhancement compared with nontargeted scTRAIL. To further assess 
Table $1 \mathrm{EC}_{50}$ values (mean \pm S.E.M.) of various TRAIL constructs on tumor cells in the presence of bortezomib/cycloheximide

\begin{tabular}{|c|c|c|c|}
\hline & HepG2 & Colo205 & Huh-7 \\
\hline 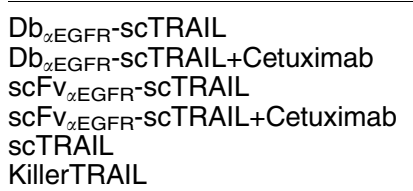 & $\begin{array}{l}5.4 \pm 3.1 \times 10^{-11} \mathrm{M} \\
5.8 \pm 2.7 \times 10^{-10} \mathrm{M} \\
5.3 \pm 2.3 \times 10^{-10} \mathrm{M} \\
2.4 \pm 0.5 \times 10^{-10} \mathrm{M}\end{array}$ & $\begin{array}{l}2.1 \pm 0.3 \times 10^{-12} \mathrm{M} \\
4.3 \pm 0.4 \times 10^{-12} \mathrm{M} \\
2.8 \pm 0.3 \times 10^{-11} \mathrm{M} \\
1.9 \pm 0.4 \times 10^{-10} \mathrm{M} \\
1.8 \pm 0.5 \times 10^{-10} \mathrm{M}\end{array}$ & $\begin{array}{l}2.7 \pm 0.5 \times 10^{-12} \mathrm{M} \\
1.6 \pm 0.5 \times 10^{-11} \mathrm{M} \\
4.3 \pm 1.2 \times 10^{-11} \mathrm{M} \\
5.0 \pm 2.3 \times 10^{-10} \mathrm{M} \\
7.0 \pm 2.3 \times 10^{-10} \mathrm{M}\end{array}$ \\
\hline
\end{tabular}

a

$$
\begin{aligned}
& \neg-\mathrm{Db}_{\alpha \mathrm{EGFR}}{ }^{-\mathrm{ScTRAIL}} \\
& \text { - Db }{ }_{\alpha \mathrm{EGFR}^{-S c T R A I L ~+~}} \\
& \text { Cetuximab } \\
& \text {-o- scFv }{ }_{\alpha E G F R} \text {-scTRAIL } \\
& \text { - } \text { - }^{\text {ScFFv }} \text { Cetuximab }^{\text {-scTRAIL + }} \\
& \text { Cetuxima } \\
& \triangle \text { scTRAIL } \\
& \rightarrow \text { KillertRAIL }
\end{aligned}
$$
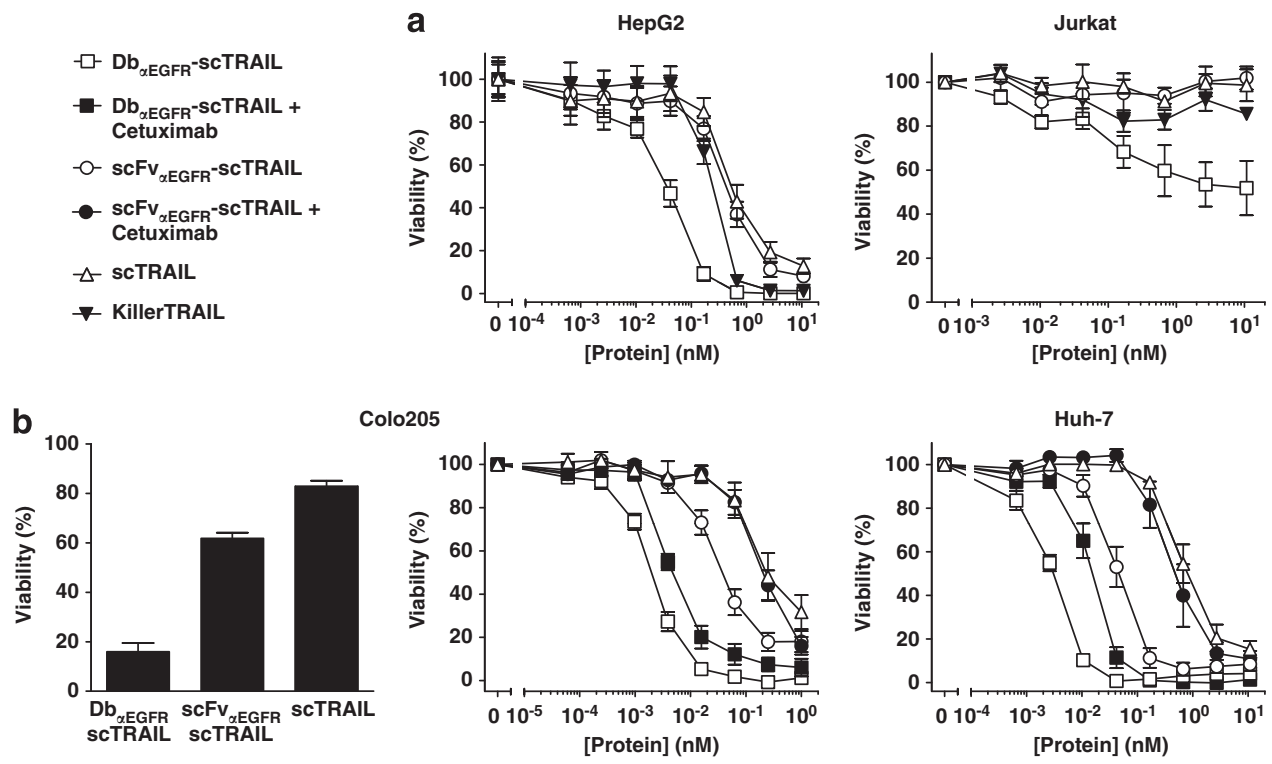

C
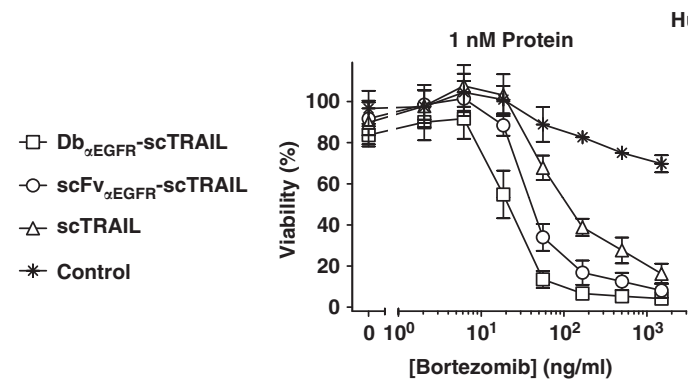

Huh-7
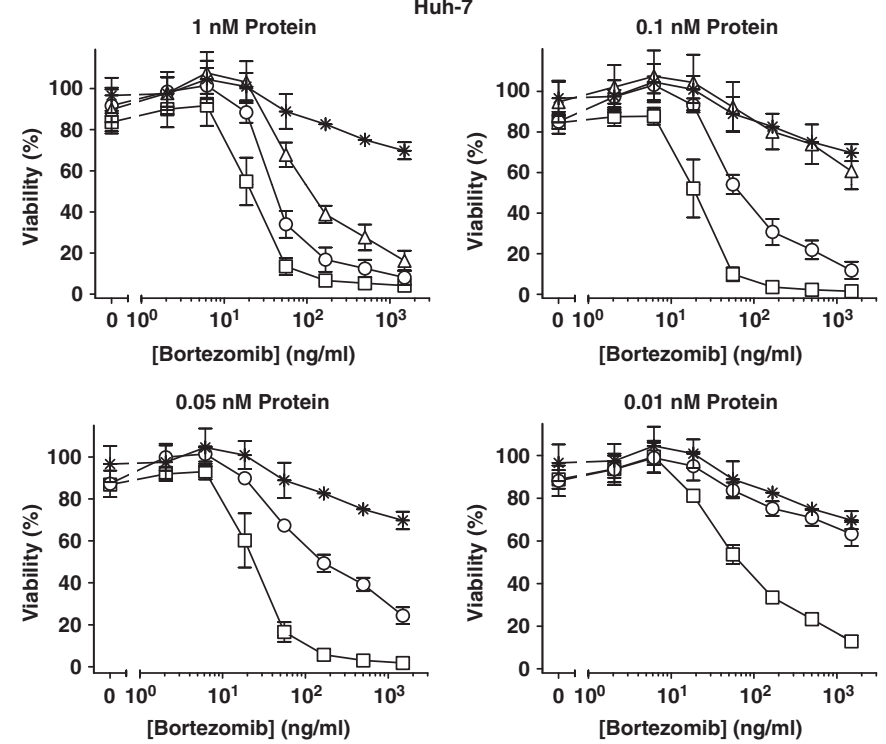

Figure 3 Target-independent and EGFR-targeted induction of cell death by scTRAIL fusions. (a) HepG2 cells (left) were sensitized with $350 \mathrm{ng} / \mathrm{ml}$ bortezomib and treated with serial dilutions of $\mathrm{Db}_{\alpha \mathrm{EGFR}}$-ScTRAIL (squares), KillerTRAIL (filled triangles), scFv ${ }_{\alpha E G F R}$-scTRAIL (circles) or scTRAIL (open triangles). After $16 \mathrm{~h}$, number of viable cells was determined using crystal violet staining (mean \pm S.E.M., $n=4$ ). Nonsensitized Jurkat cells (right) were assayed analogously, followed by determination of cell viability using the MTT method (mean \pm S.E.M., $n=3$ ). (b) Colo205 colon carcinoma (left and middle, mean \pm S.E.M., $n=3$ ) or Huh-7 hepatocarcinoma cells (right, mean \pm S.E.M., $n=4$ ) were sensitized with bortezomib (left, $400 \mathrm{ng} / \mathrm{ml}$; right, $250 \mathrm{ng} / \mathrm{ml}$ ) or CHX (middle, $2.5 \mu \mathrm{g} / \mathrm{ml}$ ) and treated with $0.63 \mathrm{nM}$ (left) or serial dilutions of Db ${ }_{\alpha E G F R}-\mathrm{ScTRAlL}$ (open squares), scFv ${ }_{\alpha E G F R}$-SCTRAIL (open circles) or SCTRAIL (triangles). After $16 \mathrm{~h}$, cell viability was determined using crystal violet staining (Huh-7) or the MTT method (Colo205). For quantification of the targeting effect, cells were preincubated with an excess of cetuximab (70 nM) before adding Db ${ }_{\alpha E G F R}{ }^{-S c T R A l L}$ (filled squares) and $\mathrm{ScFV}_{\alpha \mathrm{EGFR}}$-ScTRAIL (filled circles). (c) Huh-7 cells were assayed essentially as in (b), but preincubated with constant concentrations of Db ${ }_{\alpha E G F R}$-ScTRAIL (squares), $\mathrm{ScFV}_{\alpha \mathrm{EGFR}}$-ScTRAIL (circles) or ScTRAIL (triangles), followed by addition of serial dilutions of bortezomib (mean \pm S.E.M., $n=3$ ). Control (asterisk), bortezomib alone 
apoptosis sensitization by bortezomib, Huh-7 cells were pretreated with a fixed dose of the ScTRAIL fusion proteins followed by titration of bortezomib (Figure $3 \mathrm{c}$ ). At a protein concentration of $\geqslant 1 \mathrm{nM}$, the tested reagents $\mathrm{Db}_{\alpha \mathrm{EGFR}}$

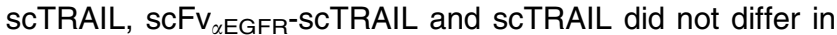
their ability to induce apoptosis in the presence of bortezomib. In contrast, at protein concentrations of $\leqslant 0.1 \mathrm{nM}$, the superior activity of targeted ScTRAIL fusion proteins became visible, with $\mathrm{Db}_{\alpha \mathrm{EGFR}}$-ScTRAIL as the most potent apoptosis inducer.

A nearly complete block of cell death by either pan-caspase (z-Val-Ala-Asp-fluoromethylketone (zVADfmk)) or caspase-3 selective (z-Asp-Glu-Val-Asp-fluoromethylketone (zDEVDfmk)) inhibitors (Figure $4 \mathrm{a}$ ) and failure of necrostatin-1 to prevent or reduce cell death (data not shown) indicated that Huh-7 and Colo205 undergo predominantly apoptotic cell death upon treatment with ScTRAIL fusion proteins. Cetuximab blocked EGF-induced autophosphorylation of EGF receptors (Figure 2d). It is well known that cetuximab only blocks liganddependent but not ligand-independent receptor tyrosine kinase (RTK) activity as a complete, divalent antibody but not as a monovalent antigen-binding fragment (Fab). ${ }^{24}$ Moreover, on appropriate target cells, cetuximab can exert growth-inhibitory and/or apoptosis-inducing activity, ${ }^{19}$ suggesting a possible contribution of the divalent EGFR targeting domain of $\mathrm{Db}_{\alpha \mathrm{EGFR}}$-ScTRAIL to the enhanced apoptosis induction. However, for the tumor cells studied here, we obtained no evidence for a TRAIL-independent cell death-inducing function of the targeting domain of $\mathrm{Db}_{\alpha \mathrm{EGFR}}{ }^{-}$ scTRAIL. First, as for the monovalent targeted $\mathrm{scFv}_{\alpha \mathrm{EGFR}^{-}}$ scTRAIL, in vitro cotreatment of $\mathrm{Db}_{\alpha \mathrm{EGFR}}$-ScTRAIL with $70 \mathrm{nM}$ cetuximab resulted in a decrease in bioactivity to the level of nontargeted ScTRAIL rather an increase in apoptosis (Figure 3b). Furthermore, cetuximab by itself, though blocking EGF-induced autophosphorylation of EGFR in Colo205 and in Huh-7 cells (Figure 2d), did not substantially affect growth of these two cancer cell lines in a 4-day culture (Figures $4 b$ and c). Similarly, when $\mathrm{Db}_{\alpha \mathrm{EGFR}}$-ScTRAIL-induced apoptosis was prevented, either by the presence of neutralizing antiTRAIL antibodies in Db ${ }_{\alpha E G F R}$-ScTRAIL-treated Colo205 cell cultures (Figure $4 \mathrm{~b}$ ) or by treating Huh-7 cell cultures with pancaspase inhibitors (Figure 4c), only a marginal growth inhibition was noted during the 4-day observation period. Together, for the cells and the in vitro conditions studied here, the data indicate that (1) $\mathrm{Db}_{\alpha \mathrm{EGFR}}$-ScTRAIL-induced cell death requires TRAIL signaling and (2) blocking EGFR function by
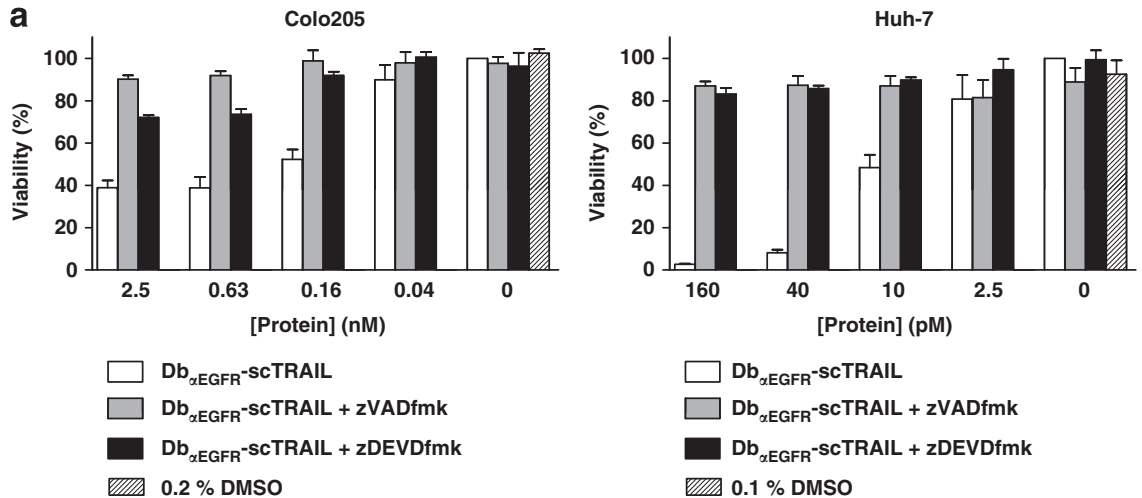

b

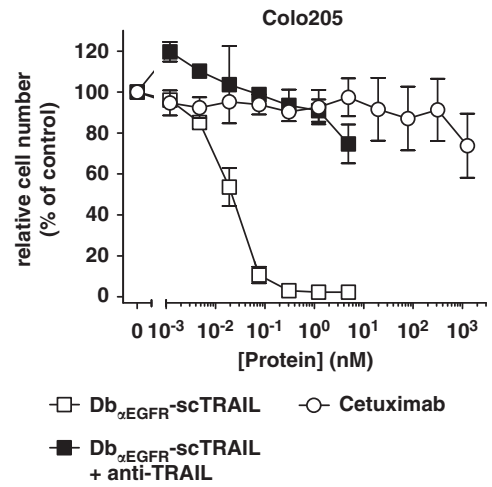

c

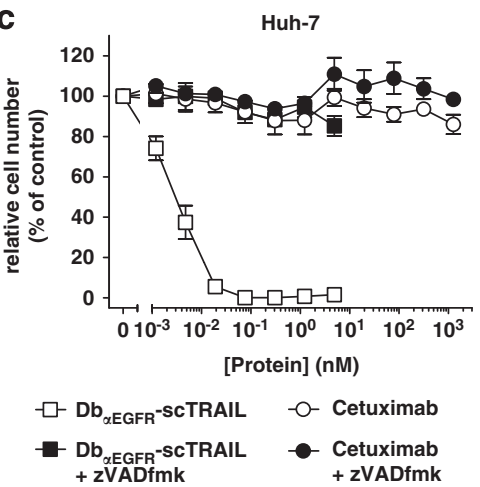

Figure 4 Caspase dependence of cell death and impact of the anti-EGFR diabody moiety of $\mathrm{Db}_{\alpha \mathrm{EGFR}}$-SCTRAIL. (a) Colo205 cells (left) and Huh-7 cells (right) were sensitized with 25 and $250 \mathrm{ng} / \mathrm{ml}$ bortezomib, respectively, and treated with different concentrations of $\mathrm{Db}_{\alpha \mathrm{EGFR}}$-ScTRAIL with or without the presence of pan-caspase inhibitor zVADfmk or caspase-3 inhibitor zDEVDfmk (both inhibitors $20 \mu \mathrm{M}$ for Colo205 and $10 \mu \mathrm{M}$ for Huh-7). After $16 \mathrm{~h}$, cell viability was determined using MTT staining (Colo205) or crystal violet staining (Huh-7) and data were normalized using bortezomib-treated cells as control (mean \pm S.E.M., $n=3$ ). (b) $1 \times 10^{4}$ Colo205 cells per well were grown in 96-well plates using medium with $0.1 \%$ FCS. Upon stimulation with $50 \mathrm{ng} / \mathrm{ml} \mathrm{EGF}$ and sensitization with $10 \mathrm{ng} / \mathrm{ml}$ bortezomib, cells were incubated with equimolar concentrations of $\mathrm{Db}_{\alpha \mathrm{EGFR}}$-SCTRAIL (open squares), Db $\mathrm{EEGFR}_{\alpha \mathrm{SCTRAIL}}+$ anti-TRAIL mAb $2 \mathrm{E} 5$ (filled squares) or cetuximab (circles) for 4 days and cell number was assayed by the MTT method using bortezomib/EGF-treated cells as control for normalization (mean \pm S.E.M., $n=2$ ). (c) $1 \times 10^{4}$ Huh-7 cells per well were grown in 96 -well plates and treated with $20 \mathrm{ng} / \mathrm{ml}$ bortezomib or with a combination of bortezomib and $10 \mu \mathrm{M}$ zVADfmk. Then, cells were incubated with equimolar concentrations of Db ${ }_{\alpha E G F R}$ SCTRAIL $^{-S_{1}}$ (open squares), $\mathrm{Db}_{\alpha \mathrm{EGFR}}$-ScTRAIL + zVADfmk (filled squares), cetuximab (open circles) or cetuximab + zVADfmk (filled circles) for 3 days and cell viability was assayed by the MTT method using bortezomib-treated cells and bortezomib/zVADfmk-treated cells, respectively, as control for normalization (mean \pm S.E.M., $n=3$ ) 
the diabody module does not contribute to rapid apoptosis induction.

In vivo tolerance of $\mathrm{Db}_{\alpha \mathrm{EGFR}}$-SCTRAIL. In order to investigate the in vivo properties of the novel fusion protein, we first checked for potential hepatotoxic effects of $\mathrm{Db}_{\alpha \mathrm{EGFR}}$ SCTRAIL and monovalent ScFv $_{\alpha E_{\text {EGFR }}}$-SCTRAIL in comparison with aggregated Fas ligand used as a positive control. To this, serum alanine aminotransaminase (serum ALT) and liver caspase-3 activities were assayed in mice after application of a high dose of the protein $(1 \mathrm{nmol})$. Both assays consistently revealed that a $\mathrm{Db}_{\alpha \mathrm{EGFR}}$-ScTRAIL dose inducing maximum apoptosis in vitro did not cause acute liver toxicity in vivo (Figure 5). Thus, mean serum ALT activities at $4 \mathrm{~h}$ after application of $\mathrm{Db}_{\alpha \mathrm{EGFR}}$-SCTRAIL $(61 \mathrm{U} / \mathrm{l})$ or ScFv $\mathrm{v}_{\alpha \mathrm{EGFR}}$-SCTRAIL $(50 \mathrm{U} / \mathrm{l})$ were only slightly and transiently raised to values considered as upper normal level $(50 \mathrm{U} / \mathrm{l})$ in humans and declined to baseline after $24 \mathrm{~h}$ (Figure $5 \mathrm{a}$ ). Analyses of caspase-3 activities from mouse liver tissue $24 \mathrm{~h}$ (5h for positive control) after in vivo fusion protein application (Figure $5 \mathrm{~b}$ ) and histological analyses of liver tissue sections (Supplementary Figure S2) revealed no evidence for acute tissue toxicity of the applied reagents. Furthermore, a comparison of Huh-7 hepatoma cells and primary human hepatocytes (PHHs) for caspase-3 activation by $\mathrm{Db}_{\alpha \mathrm{EGFR}}{ }^{-}$ ScTRAIL in the presence of bortezomib showed a strong, bortezomib-dependent caspase-3 activation in the tumor cells, whereas normal liver cells were neither affected by the scTRAIL fusion protein alone nor in combination with bortezomib (Figure 5c). These results were confirmed by immunoblot analysis of cleaved caspase-3 in Huh-7 and PHHs, with no detectable caspase activation in combination-treated $\mathrm{PHHs}$, whereas robust caspase processing was detectable in sensitive Huh-7 carcinoma cells (Figure $5 d$ ).

Antitumoral activity of $\mathrm{Db}_{\alpha \mathrm{EGFR}}$-ScTRAIL in a xenograft tumor model. We investigated the in vivo antitumoral activity of $\mathrm{Db}_{\alpha \mathrm{EGFR}}$-SCTRAIL in nude mice carrying Colo205 carcinomas (Figure 6). Given the in vitro data, showing superior bioactivity of $\mathrm{Db}_{\alpha \mathrm{EGFR}}$-SCTRAIL compared with SCFV $\mathrm{V}_{\alpha \mathrm{EGFR}}$-SCTRAIL or SCTRAIL in particular at low protein concentrations, eight doses of $0.45 \mathrm{nmol}$ protein were injected intraperitoneally (i.p.) in a daily regimen in combination with bortezomib cotreatment every second day. The systemic treatment started after establishment of solid, vascularized tumors, and tumor growth was monitored for 22 days. Bortezomib treatment by itself did not interfere with progressive tumor growth, whereas SCTRAIL and $\mathrm{SCFV}_{\alpha \mathrm{EGFR}}$-SCTRAIL both delayed tumor growth but, at the low dosage applied, did not induce regression of tumors. In contrast, upon $\mathrm{Db}_{\alpha \mathrm{EGFR}}$-ScTRAIL treatment, a strong reduction of tumor size and prolonged survival in all animals, with macroscopically undetectable tumors in 11/12 (+ bortezomib) and 9/12 (w/o bortezomib) cases, was recorded (Figure 6). Interestingly, under the treatment conditions applied, there was only a slight, but statistically not significant, benefit of cotreatment with bortezomib, although at termination of treatment the combination group presented with slower regrowth of tumors (Figure 6a).

\section{Discussion}

In this study we present a new format of TRAIL fusion proteins based on directed dimerization with strongly

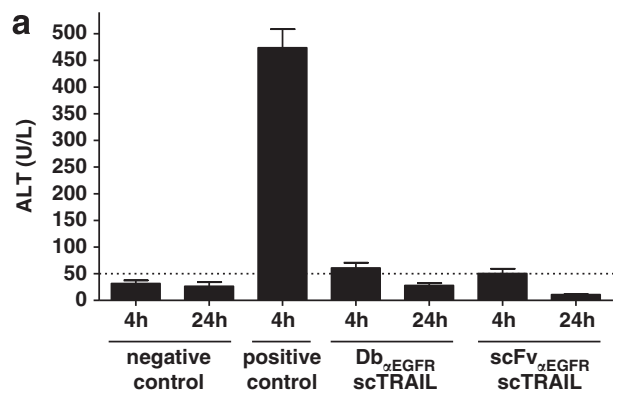

b
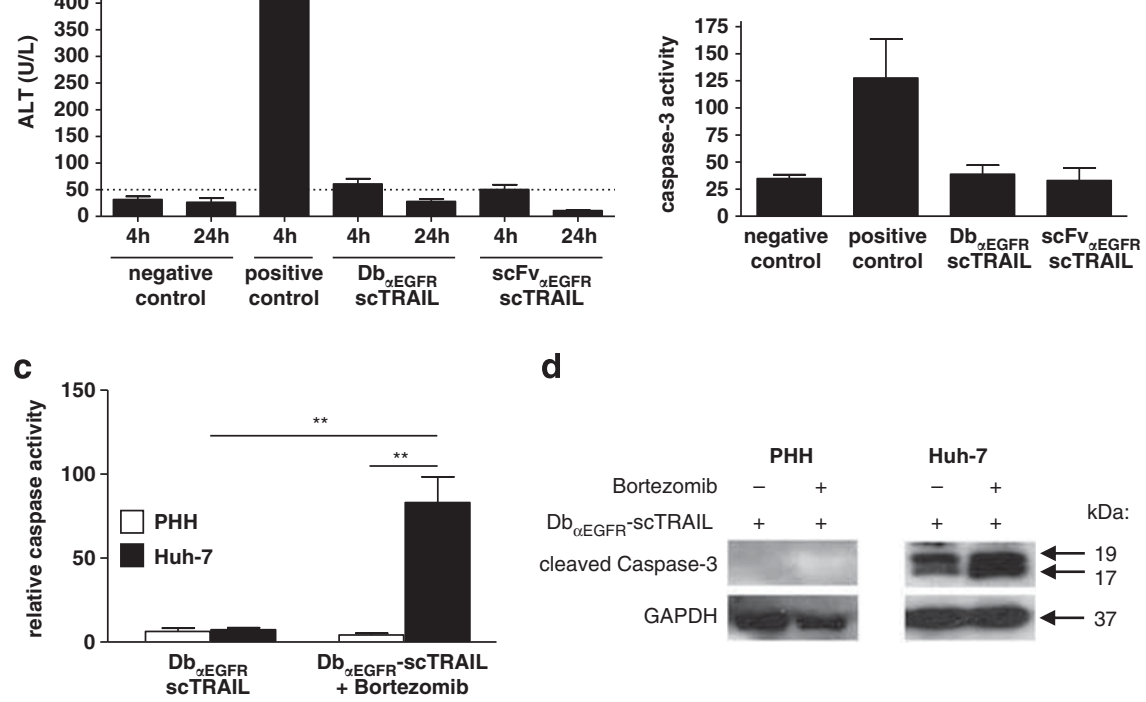

d

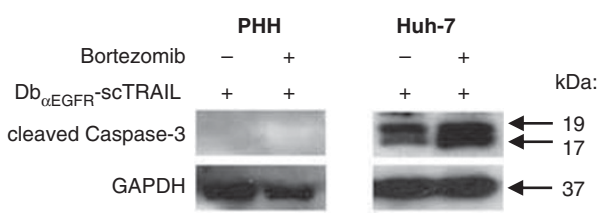

Figure 5 Systemic and in vitro tolerance of scTRAIL fusion proteins to primary tissues. (a) Alanine aminotransaminase (ALT) activity in mouse serum after in vivo i.p. application of $1 \mathrm{nmol}^{\mathrm{Db}_{\alpha E G F R}-\mathrm{ScTRAIL} \text { or ScFV }}{ }_{\alpha E G F R}$-ScTRAIL (mean \pm S.E.M., $n=3$ ). Positive control, $0.1 \mathrm{nmol}$ Fas ligand fusion protein; negative control, PBS; Dotted line, upper normal level $(50 \mathrm{U} / \mathrm{l})$. (b) Caspase-3 activities in mouse liver biopsies at the end point of the previous experiment. (c) Relative caspase activity (fold increase compared with untreated) in primary human hepatocytes (PHHs, mean \pm S.E.M., $n=5$ ) or Huh-7 hepatocarcinoma cells (mean \pm S.E.M., $n=7$ ) after incubation with $1.1 \mathrm{nM} \mathrm{Db} \mathrm{EGGFR}^{-}$ scTRAIL in the presence or without $500 \mathrm{ng} / \mathrm{ml}$ bortezomib. Asterisks indicate statistical significance. (d) Cleavage of caspase-3 in PHH (left) and Huh-7 cells (right) after

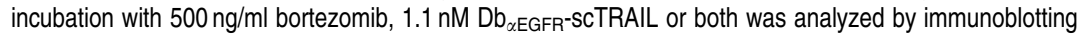




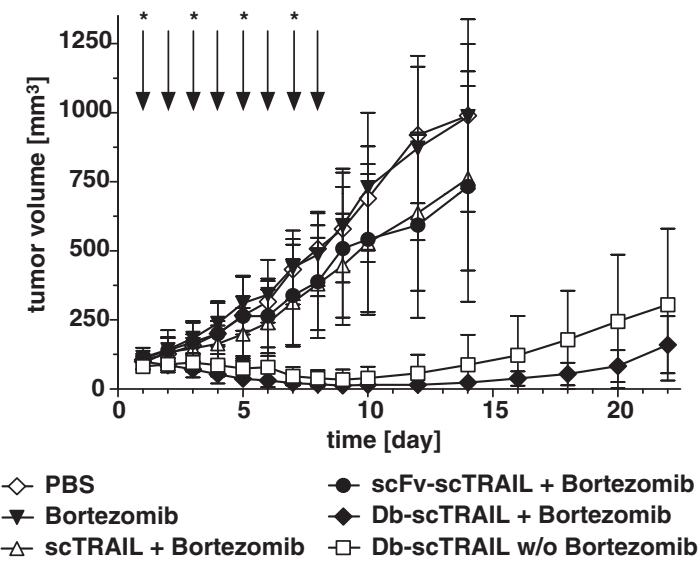

b

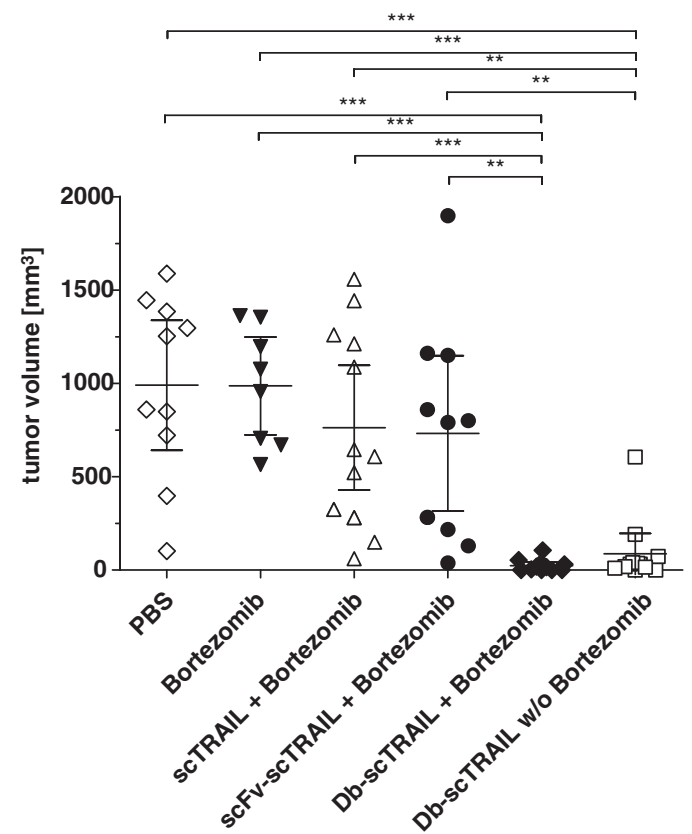

Figure 6 Antitumor activity of TRAIL fusion proteins in a Colo205 xenograft tumor model. (a) Tumor volume as a function of time after i.p. application of PBS (open diamonds), bortezomib (filled triangles), scTRAIL + bortezomib (open

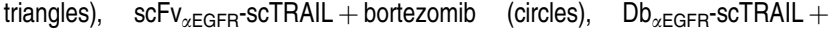
bortezomib (filled diamonds) or $\mathrm{Db}_{\alpha \mathrm{EGFR}}$-scTRAIL only (squares). Arrows, protein application; asterisks, bortezomib application; symbols, mean of tumor volumes $\pm 95 \%$ confidence interval $(\mathrm{Cl}), n=12$ tumors/treatment group. (b) Individual tumor volumes at day 14 . Bars, mean of tumor volumes $\pm 95 \% \mathrm{Cl}$

increased tumor-targeted bioactivity and devoid of systemic toxicity of these TRAIL fusion proteins. We and others previously showed that proapoptotic ligands of the TNF family can be engineered to exert stronger antitumor activity by creation of single-chain molecule ${ }^{25}$ and by targeting death ligands to cell surface-expressed tumor antigens by fusion to a tumor-specific scFv. ${ }^{16,26}$ Tumor-targeted scFv-TRAIL fusion proteins can mimic the naturally membrane-bound form of the ligand enabling DR4- and particularly DR5-mediated apoptosis induction, which is poorly exerted by soluble forms of TRAIL. ${ }^{21,27,28}$ In support of this, we have recently shown that a fusion protein comprising ScFv and single-chain TRAIL is a preferred format compared with nontargeted TRAIL in terms of bioactivity in vitro and in vivo. ${ }^{16}$

Aside from targeting through scFv, bioactivity of death ligands can be considerably increased through oligomerization. ${ }^{29}$ However, this may lead to generalized systemic toxicity, particularly evident for acute liver toxicity induced by Fas-specific reagents. ${ }^{30}$ Similarly, for TRAIL, off-target toxicity of uncontrolled oligomeric forms of TRAIL has been reported. ${ }^{31}$ We reasoned that a combination of antigen targeting and controlled TRAIL oligomerization should, on respective target cells, result in an effective activation of TRAIL DRs, and in particular DR5, which is the major proapoptotic TRAILR in carcinoma cells. ${ }^{32}$ With the forced

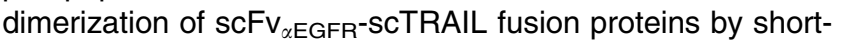
ening the linkers between $V_{H}$ and $V_{L}$ to five amino-acid residues, we generated a $\mathrm{Db}_{\alpha E G F R}$-ScTRAIL fusion protein exhibiting bivalent antigen binding and dimeric scTRAIL configuration, which meets the above criteria. In addition to the dimers, a minor species of higher molecular mass, likely trimeric or tetrameric fusion proteins, was detected by gel filtration of affinity-purified $\mathrm{Db}_{\alpha \mathrm{EGFR}}$-SCTRAIL. We assume that the scTRAIL moiety of the fusion protein has an additional influence on oligomerization, because higher-order oligomeric species were not found when the $\alpha$ EGFR diabody was expressed as a single protein (data not shown). However, we propose that such oligomeric assemblies do not provide a further advantage with regard to bioactivity, compared with the dimeric $\mathrm{Db}_{\alpha \mathrm{EGFR}}$-SCTRAIL form. First, cell death assays using the separated species gave no hint for a different bioactivity of both isoforms. Second, an engineered protein format with an at least trimeric assembly of $\mathrm{SCFV}_{\alpha \mathrm{EGFR}}$-SCTRAIL showed again no better activity in vitro as compared with $\mathrm{Db}_{\alpha \mathrm{EGFR}}$-SCTRAIL (A Benk and $M$ Siegemund, unpublished data).

We found that $\mathrm{Db}_{\alpha \mathrm{EGFR}}$-SCTRAIL has a higher affinity to target-positive tumor cells than $\mathrm{SCFv}_{\alpha \mathrm{EGFR}}$-SCTRAIL, evident from an approximately twofold lower $\mathrm{EC}_{50}$ at $4{ }^{\circ} \mathrm{C}$. Both the diabody configuration and the dimeric status of SCTRAIL could contribute to this apparent affinity increase. However, we attribute this largely to a better avidity of the bivalent diabody targeting module, as dynamic clustering of TRAILRs and therefore stable receptor ligand interactions are prevented under the applied assay conditions. Independent evidence for increased avidity of $\mathrm{Db}_{\alpha \mathrm{EGFR}}$-ScTRAIL is obtained from the reduced efficacy of cetuximab in competing the binding of $\mathrm{Db}_{\alpha \mathrm{EGFR}}$-ScTRAIL to $\mathrm{EGFR}^{+}$cells as compared with scFv $v_{\alpha E G F R}$-ScTRAIL. Accordingly, we postulate that a more stable receptor interaction of $\mathrm{Db}_{\alpha E G F R}$-SCTRAIL supports clustering and subsequent DISC formation of death receptors in specific membrane compartments, for example lipid rafts, which have been proposed to play an important role in DR4 and DR5 signal transduction. ${ }^{33,34}$ Our data support this reasoning by showing enhanced bioactivity of the $\mathrm{Db}_{\alpha \mathrm{EGFR}}{ }^{-}$ ScTRAIL molecules, to which both targeting and the dimeric/ oligomeric assembly of the TRAIL molecule itself contribute, resulting in an overall greater 100 -fold increased bioactivity on target-positive tumor cells. In contrast, on target-negative tumor cell lines like HepG2 or Jurkat, the dimeric scTRAIL configuration exclusively seems to contribute to an activity increase compared with scTRAIL. 
The $\mathrm{Db}_{\alpha \mathrm{EGFR}}$-scTRAIL comprises two scFvs derived from the mAb cetuximab, an EGF-blocking, antagonistic antibody reported to be capable of growth inhibition and/or apoptosis induction in some tumor cells. ${ }^{19,20}$ Although we confirmed blocking of EGF-induced EGFR autophosphorylation in the tumor cells studied here, it was interesting to note that this RTK inhibition did not apparently contribute to the enhancement of TRAIL-induced apoptosis, at least as detectable within short-term in vitro assays. Lack of an active contribution of EGFR blocking to apoptosis sensitivity was particularly evident from a right shift in the dose-response curves to a level of nontargeted TRAIL molecules when cetuximab was added to $\mathrm{Db}_{\alpha \mathrm{EGFR}}$-ScTRAIL-treated cells. Moreover, the block of $\mathrm{Db}_{\alpha \mathrm{EGFR}}$-ScTRAIL-mediated cell death by TRAIL-neutralizing antibodies confirms that the apoptotic signal emanated from TRAILRs. Accordingly, the strongly enhanced apoptotic activity of $\mathrm{Db}_{\alpha \mathrm{EGFR}}$-SCTRAIL is an intrinsic molecular feature of this bifunctional protein, in which EGFR targeting and presentation of TRAIL to its cognate DRs cannot be mimicked by cooperative action of two independent molecules, one interfering with EGFR activity and one inducing apoptosis via TRAIL DRs. However, these in vitro studies do not rule out a contribution of EGFR inhibition by the ScFv module in the observed in vivo antitumoral activity of $\mathrm{Db}_{\alpha \mathrm{EGFR}}$-SCTRAIL, where several additional parameters aside from basal apoptosis sensitivity affect tumor outgrowth and responsiveness to drug treatment.

Strongly enhanced bioactivity and improved pharmacokinetics of targeted scTRAIL fusion proteins (see Schneider et al. ${ }^{16}$ and this study) appear mandatory to reach significant clinical responses under TRAIL therapy. However, considering previous reports on the potential loss of tumor selectivity of aggregated or artificially crosslinked TRAIL forms, ${ }^{15,35,36}$ the oligomeric nature of $\mathrm{Db}_{\alpha \mathrm{EGFR}}$-scTRAIL demands a thorough analysis of potential off-target action and systemic toxicity. Toward this end, we obtained evidence that $\mathrm{Db}_{\alpha \mathrm{EGFR}}{ }^{-}$ ScTRAIL was surprisingly well tolerated in mice at doses up to $3 \mathrm{mg} / \mathrm{kg}$ with no evidence for acute hepatotoxicity, judged from ALT levels and histopathological analyses. In vitro $\mathrm{Db}_{\alpha \mathrm{EGFR}}$-ScTRAIL treatment of primary human hepatocytes with or without apoptosis sensitizer bortezomib did not induce caspase activation, thus fully confirming the mouse in vivo data. Additionally, healthy human liver tissue from in vitro cultures proved to be resistant toward $\mathrm{Db}_{\alpha \mathrm{EGFR}}$-SCTRAIL in the presence of the apoptosis sensitizer bortezomib also (H Bantel et al., unpublished data).

On top of a good in vivo tolerance, a superior in vivo antitumoral activity of $\mathrm{Db}_{\alpha \mathrm{EGFR}}$-scTRAIL against xenotransplanted Colo205 cells was found. Interestingly, in this in vivo tumor model, $\mathrm{Db}_{\alpha \mathrm{EGFR}}$-ScTRAIL was very effective even in the absence of the apoptosis sensitizer bortezomib, although after termination of short-term therapy, tumor regrowth was detectable earlier in this group as compared with the combination therapy group. A potentially greater benefit of combination therapy might become evident under a different therapeutic regimen and/or only in long-term studies. In contrast, in preliminary in vivo studies with the hepatocellular carcinoma cells Huh-7, the antitumoral activity of different scTRAIL derivatives, including $\mathrm{Db}_{\alpha \mathrm{EGFR}}$-ScTRAIL, was only revealed in the presence of bortezomib (A Vogel, unpublished data), which corresponded to the strict dependence of in vitro TRAIL sensitivity on bortezomib of this particular cell line. This is in accordance with published data of bortezomib as an effective sensitizer of apoptosis. ${ }^{9,37}$

In conclusion, we have shown that by genetic engineering, controlled dimerization and tumor targeting can be combined to create bifunctional fusion proteins with enforced apoptosis induction under maintenance of systemic tolerance, which exceeds the functional activities of conventional and other antigen-targeted TRAIL molecules. Specifically, combining targeting domains with intrinsic antagonistic activity toward a targeted growth factor receptor with death ligands engineered for improved apoptotic activity could potentially synergize to further enhance the antitumor activity. Although for the tumor model studied here, this bifunctionality of $\mathrm{Db}_{\alpha \mathrm{EGFR}}$-SCTRAIL appeared dispensable for in vitro apoptosis induction, it might be of particular relevance in vivo for tumors that are still growth factor dependent. Because of the modular nature of the fusion protein, the concept shown here for EGFR targeting can be exploited for a broad range of tumors for which selective cell surface markers are known.

\section{Materials and Methods}

Plasmids and cell lines. The pIRESpuro-scTRAIL expression construct for human ScTRAIL was obtained by EcoRI/Notl cloning of a synthesized sequence encoding three TRAIL modules (aa residues 95-281) connected by (GGGS) linkers into a construct described previously. ${ }^{16}$

For generation of the EGFR-specific pCR3-scFv-scTRAIL expression construct, a synthesized coding sequence of a humanized scFv 'huC225' (RE Kontermann, unpublished data) was amplified using the oligonucleotides $5^{\prime}$-CGAGGTGCAGCT GGTCGAG-3' and $5^{\prime}$-TGCGGCCGCTCTCTTGATTTC- $3^{\prime}$. Next, this template was annealed with the oligonucleotide $5^{\prime}$-ATATATCTCGAGGCCAGCGACTACAAAG ACGATGACGATAAAGGAGCCGAGGTGCAGCTGGTCGAG-3' to insert an Xhol site and a FLAG tag coding sequence. After strand elongation, the oligonucleotides 5'-ATATATCTCGAGGCCAGCGAC-3' and 5'-ATATGAATTCTGCGGCCGCTCTC TTGATTTC-3' were used for PCR. The product was cloned via Xhol/EcoRI into pCR3 (Invitrogen, Karlsruhe, Germany), carrying a $\mathrm{V}_{\mathrm{H}}$ leader and a dummy scFv-scTRAIL sequence. The ScTRAIL coding sequence of this construct ${ }^{16}$ was then substituted with scTRAIL ((GGGS) $)_{2}$ linkers) via EcoRI/Xbal.

The EGFR-specific pCR3-Db-scTRAIL expression construct was derived from pCR3-scFv ${ }_{\alpha E G F R}$-SCTRAIL by shortening the scFv linker from (GGGGS) ${ }_{3}$ to GGGGS. Therefore, two $P C R$ products were generated using the oligonucleotides (1) $5^{\prime}$-CCCACAGCCTCGAGGCCAG-3' and (2) 5'-GAGCCGCCACCGCCACT AG-3' as well as (3) $5^{\prime}$-CTAGTGGCGGTGGCGGCTCTGATATTCAGCTGACC CAGTCC- $3^{\prime}$ and (4) $5^{\prime}$-TGAATTCTGCGGCCGCTCTC- ${ }^{\prime}$. After annealing of the products at the underlined regions and strand elongation, the whole sequence was amplified by the oligonucleotides (1) and (4) followed by Xhol/Notl cloning into pCR3-sCFv ${ }_{\alpha E G F R}$-SCTRAIL.

HEK293, HepG2, NCl-H460, Colo205 and Jurkat cells were obtained from the ATCC (Manassas, VA, USA). Huh-7 cells were obtained from the JCRB (Osaka, Japan). Cells were cultured in RPMI-1640 medium (Invitrogen) supplemented with $5 \%$ fetal calf serum (FCS; HyClone, South Logan, UT, USA), excepting HepG2, Colo205 and Huh-7, where 10\% FCS was added to the medium. PHHs were isolated according to a well-defined standard procedure. ${ }^{38}$

Production and purification of recombinant proteins. TRAIL fusion proteins were produced in HEK293 cells as published, ${ }^{16}$ and purified from supernatants first by immobilized metal affinity chromatography (IMAC) based on affinity of TRAIL to Ni-NTA-Agarose (Qiagen, Hilden, Germany). After elution with $100 \mathrm{mM}$ imidazol in IMAC buffer $\left(50 \mathrm{mM} \mathrm{NaH}_{2} \mathrm{PO}_{4}, \mathrm{pH} 8.0,300 \mathrm{mM} \mathrm{NaCl}\right)$ and dialysis against PBS, the proteins were further purified by affinity chromatography using anti-FLAG mAb M2 agarose (Sigma-Aldrich, Steinheim, Germany) according to the manufacturer's protocol. ScTRAIL was purified by M2 agarose only. After elution of bound proteins with $100 \mu \mathrm{g} / \mathrm{ml}$ FLAG peptide (Peptides \& elephants, Potsdam, Germany) and dialysis against PBS, proteins were concentrated with 
Vivaspin devices (PES membrane with 50 or $10 \mathrm{kDa}$ molecular weight cutoff; Sartorius Stedim, Aubagne, France). The protein concentration was measured with a spectrophotometer (NanoDrop Products, Wilmington, DE, USA) and aliquots were stored at $-80^{\circ} \mathrm{C}$.

Immunoprecipitation and protein analysis. For immunoprecipitations, cells were lysed on ice in RIPA buffer $(50 \mathrm{mM}$ Tris, $\mathrm{pH} 7.5,150 \mathrm{mM} \mathrm{NaCl}, 10 \mathrm{mM}$ sodium fluoride, $20 \mathrm{mM} \beta$-glycerophosphate, $1 \mathrm{mM}$ EDTA, 1\% NP-40, $1 \mathrm{mM}$ sodium orthovanadate, $0.5 \mathrm{mM}$ phenylmethylsulfonyl fluoride, $0.1 \%$ SDS, $0.25 \%$ sodium deoxycholate) with Complete protease inhibitor (Roche Diagnostics, Mannheim, Germany) and lysates were clarified by centrifugation $\left(16000 \times g, 10 \mathrm{~min}, 4^{\circ} \mathrm{C}\right)$. Then, $1.5 \mathrm{mg}$ lysate protein was incubated with $1.5 \mu \mathrm{g}$ mouse anti-EGFR Ab-13 $\mathrm{mAb}$ (Neomarkers, Fremont, CA, USA) under gentle shaking at $4{ }^{\circ} \mathrm{C}$ overnight. Immune complexes were captured with protein G sepharose (KPL, Gaithersburg, $M D$, USA) and washed three times with RIPA buffer. Proteins were analyzed by SDS-PAGE and western blotting using mouse anti-phosphotyrosine P-Tyr-100 mAb (Cell Signaling Technology, Danvers, MA, USA) and rabbit anti-EGFR 1005 antibody (Santa Cruz Biotechnology, Santa Cruz, CA, USA) followed by horseradish peroxidase (HRP)-conjugated secondary antibodies. Enhanced chemoluminescence (ECL; Pierce Biotechnology, Rockford, IL, USA) was used for visualization.

Caspases were detected by immunoblotting using a rabbit polyclonal antibody against cleaved caspase-3 (Cell Signaling Technology). Glyceraldehyde 3-phosphate dehydrogenase (GAPDH) as internal control was detected with a rabbit polyclonal antibody (Cell Signaling Technology). HRP-conjugated secondary antibodies (Zymed Laboratories, San Francisco, CA, USA) and ECL were used for visualization.

Affinity-purified ScTRAIL fusion proteins were analyzed by SDS-PAGE and silver staining (Sigma-Aldrich). For western blotting, anti-TRAIL MAB687 (R\&D Systems, Wiesbaden, Germany) and anti-FLAG M2 mAbs (Sigma-Aldrich) were used, followed by anti-mouse alkaline phosphatase-coupled secondary antibody (Sigma-Aldrich) for detection. For size exclusion chromatography, proteins were applied to a BioSuite250 HR SEC $300 \times 7.8 \mathrm{HPLC}$ column (Waters, Milford, MA, USA) equilibrated in PBS and eluted at a flow rate of $0.5 \mathrm{ml} / \mathrm{min}$.

Flow cytometry. $5 \times 10^{5}$ cells were suspended in PBA buffer (PBS, $0.025 \%$ BSA, $0.02 \% \mathrm{NaN}_{3}$ ) and incubated for $1 \mathrm{~h}$ at $4{ }^{\circ} \mathrm{C}$ with the ScTRAIL fusion proteins $(2 \mu \mathrm{g} / \mathrm{ml})$. After washing the cells three times with PBA buffer, bound proteins were detected by anti-human TRAIL mAb MAB687 $(2.5 \mu \mathrm{g} / \mathrm{ml})$ and fluorescein isothiocyanate (FITC)-labeled rabbit anti-mouse IgG $A b(1: 200$, Sigma-Aldrich), followed by three washing steps with PBA each. For blocking of ScTRAIL fusion protein binding to EGFRs, a divalent variant of scFv huC225 (scFv huC225Cys, $50 \mu \mathrm{g} / \mathrm{ml}$, kindly provided by Celonic $\mathrm{GmbH}$, Jülich, Germany) was added $30 \mathrm{~min}$ before incubation with $S C \mathrm{Fv}_{\alpha E G F R}$-SCTRAIL or $\mathrm{Db}_{\alpha \mathrm{EGFR}}$-SCTRAIL, respectively. TRAIL receptors were detected by anti-TRAIL R1 mAb MAB347 and anti-TRAIL R2 $\mathrm{mAb}$ MAB6311 (4 $\mu \mathrm{g} / \mathrm{ml}$ each, R\&D Systems) in conjunction with anti-mouse lgGFITC. EGF receptors were detected by a phycoerythrin-labeled anti-human EGFR mAb sc-101 (4 $\mu \mathrm{g} / \mathrm{ml}$, Santa Cruz Biotechnology). For binding competition, purified

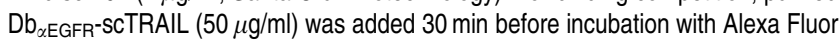
488-coupled (Life Technologies) mAb cetuximab $(1 \mu \mathrm{g} / \mathrm{ml})$.

Binding of scTRAIL fusion proteins to EGFR-expressing NCI-H460 cells was analyzed by flow cytometry at $4{ }^{\circ} \mathrm{C}$ as described. ${ }^{39,40}$ Cells were incubated with antiTRAIL mAb MAB687 $(2.5 \mu \mathrm{g} / \mathrm{ml})$ and FITC-labeled rabbit anti-mouse IgG Ab $(1: 200)$ in the presence of cell-bound protein or without (background control). Data were fitted with Prism (GraphPad Software, La Jolla, CA, USA) from four independent binding curves, and mean $\mathrm{EC}_{50}$ values \pm S.E.M. were calculated. For statistical analysis, Student's $t$-test was applied.

Cell death assays. Huh-7 $\left(2.5 \times 10^{4}\right.$ per well), HepG2 $\left(3 \times 10^{4}\right.$ per well), Colo205 $\left(5 \times 10^{4}\right.$ per well) or Jurkat cells $\left(1 \times 10^{5}\right.$ per well) were grown in $100 \mu \mathrm{l}$ culture medium in 96 -well plates for $24 \mathrm{~h}$, followed by treatment with serial dilutions of scTRAIL fusion proteins or 'KillerTRAIL' (Enzo Life Sciences, Lörrach, Germany) in triplicates. For positive control, cells were killed with $0.25 \%$ Triton X-100. Cell death assays were performed in the absence or presence of bortezomib (20-250 ng/ml for Huh-7, $350 \mathrm{ng} / \mathrm{ml}$ for HepG2, $10-400 \mathrm{ng} / \mathrm{ml}$ for Colo205; Selleck Chemicals, Houston, TX, USA) or CHX (2.5 $\mu \mathrm{g} / \mathrm{ml}$ for Colo205; SigmaAldrich). Bortezomib/CHX was added $30 \mathrm{~min}$ before incubation with the proapoptotic ligands to sensitize carcinoma cells for cell death induction. Appropriate concentrations of caspase inhibitors zVADfmk and zDEVDfmk (10 mM stock solutions in DMSO; Enzo Life Sciences) were added to the bortezomib solution. Where applicable, the EGFR signaling pathway was induced by $50 \mathrm{ng} / \mathrm{ml}$ EGF (Sigma-Aldrich). Alternatively, cells were preincubated for $30 \mathrm{~min}$ with the proapoptotic ligands followed by addition of serial dilutions of bortezomib. After $16 \mathrm{~h}$ of incubation, cell viability was determined either by crystal violet staining (Huh-7, HepG2) or the 3-(4,5-dimethylthiazol-2-yl)-2,5-diphenyltetrazolium bromide (MTT) method (Jurkat, Colo205). ${ }^{41}$ For the MTT assay, cells were lysed in DMF/ $/ \mathrm{H}_{2} \mathrm{O}$ $(1: 1), 15 \%$ SDS, pH 4.5. To demonstrate target antigen-dependent induction of cell death, cells were preincubated for 30 min with competing cetuximab $\mathrm{mAb}(10 \mu \mathrm{g} / \mathrm{ml}$, Merck KGaA, Darmstadt, Germany) or alternatively scFv huC225Cys $(10 \mu \mathrm{g} / \mathrm{ml})$. For inhibition of TRAIL bioactivity, neutralizing anti-TRAIL antibody 2E5 $(1 \mu \mathrm{g} / \mathrm{ml}$, Enzo Life Sciences) was used.

ALT and caspase activities. Groups of three CD1 mice (Janvier, Le Genest-St-Isle, France) were treated i.p. with $1 \mathrm{nmol} \mathrm{Db}_{\alpha \mathrm{EGFR}}$-SCTRAIL and

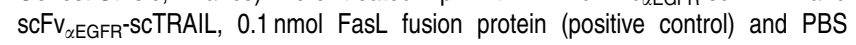
(negative control). Blood samples were taken from the tail after 4 and $24 \mathrm{~h}$ and incubated on ice. Clotted blood was centrifuged $\left(10000 \times \mathrm{g}, 10 \mathrm{~min}, 4^{\circ} \mathrm{C}\right)$ and serum samples were stored at $-80^{\circ} \mathrm{C}$. Activity of ALT was determined by an enzymatic assay (BIOO Scientific, Austin, TX, USA). To determine caspase-3 activity in the liver tissue, mice were killed after $24 \mathrm{~h}$ (positive control after $5 \mathrm{~h}$ ) and liver biopsies were taken. Homogenates were prepared in lysis buffer $(200 \mathrm{mM}$ $\mathrm{NaCl}, 20 \mathrm{mM}$ Tris, $1 \% \mathrm{NP}-40, \mathrm{pH}$ 7.4). Then, $10 \mu \mathrm{g}$ of protein was analyzed by conversion of the fluorogenic substrate Ac-Asp-Met-GIn-Asp-7-Amino-4methylcoumarin (Ac-DMQD-AMC; Enzo Life Sciences). Caspase activity in PHH and Huh-7 cells was determined as published. ${ }^{42}$

Xenograft mouse tumor model. Female NMRI nu/nu mice (Janvier), 8 weeks old, were injected subcutaneously (s.c.) with $3 \times 10^{6}$ Colo205 cells in $100 \mu \mathrm{l}$ PBS at left and right dorsal sides. Treatment started 6 days after tumor cell inoculation when tumors reached $\sim 100 \mathrm{~mm}^{3}$. Mice received 8 daily i.p. injections of $0.45 \mathrm{nmol}$ of the affinity-purified TRAIL fusion proteins. On days $1,3,5$ and 7 of treatment, mice received additionally $5 \mu \mathrm{g}$ bortezomib in $100 \mu \mathrm{l}$ PBS i.p. $3 \mathrm{~h}$ before protein injection. The control groups received $100 \mu \mathrm{l}$ PBS or $5 \mu \mathrm{g}$ bortezomib at the same time intervals. Tumor growth was monitored as described. ${ }^{16,43}$ Tukey's test was applied for statistics.

\section{Conflict of Interest}

University of Stuttgart has filed a patent application on the TRAIL fusion proteins described in this report with K Pfizenmaier, RE Kontermann and M Siegemund named as inventors. The other authors declare no conflict of interest.

Acknowledgements. We thank Amelie Benk for sharing data on trimerized TRAIL fusion proteins and Verena Berger for supporting the production of recombinant proteins. This study was supported by the Deutsche Forschungsgemeinschaft (SFB Transregio 77) and BMBF FORSYS Partner (Project No. 0315-280A).

1. Amm HM, Oliver PG, Lee CH, Li Y, Buchsbaum DJ. Combined modality therapy with TRAIL or agonistic death receptor antibodies. Cancer Biol Ther 2011; 11: 431-449.

2. Holland PM. Targeting Apo2LTRAIL receptors by soluble Apo2L/TRAIL. Cancer Lett 2011; e-pub ahead of print 8 January 2011; doi:10.1016/j.canlet.2010.11.001.

3. Belada D, Mayer J, Czuczman MS, Flinn IW, Durbin-Johnson B, Bray GL. Phase II study of dulanermin plus rituximab in patients with relapsed follicular non-Hodgkin's lymphoma (NHL). ASCO Meeting Abstracts 2010; 28: 8104.

4. Hörnle M, Peters N, Thayaparasingham B, Vörsmann H, Kashkar H, Kulms D. Caspase-3 cleaves XIAP in a positive feedback loop to sensitize melanoma cells to TRAlL-induced apoptosis. Oncogene 2011; 30: 575-587.

5. Volkmann M, Schiff JH, Hajjar Y, Otto G, Stilgenbauer F, Fiehn W et al. Loss of CD95 expression is linked to most but not all p53 mutants in European hepatocellular carcinoma. J Mol Med 2001; 79: 594-600.

6. Chan C, Yau T, Jin D, Wong C, Fan S, Ng IO. Evaluation of nuclear factor-kappaB, urokinase-type plasminogen activator, and $\mathrm{HBx}$ and their clinicopathological significance in hepatocellular carcinoma. Clin Cancer Res 2004; 10: 4140-4149.

7. Haybaeck J, Zeller N, Wolf MJ, Weber A, Wagner U, Kurrer MO et al. A lymphotoxin-driven pathway to hepatocellular carcinoma. Cancer Cell 2009; 16: 295-308.

8. Koehler B, Urbanik T, Vick B, Boger R, Heeger S, Galle P et al. TRAlL-induced apoptosis of hepatocellular carcinoma cells is augmented by targeted therapies. World $\mathrm{J}$ Gastroenterol 2009; 15: 5924-5935. 
9. Ganten TM, Koschny R, Haas TL, Sykora J, Li-Weber M, Herzer K et al. Proteasome inhibition sensitizes hepatocellular carcinoma cells, but not human hepatocytes, to TRAIL. Hepatology 2005; 42: 588-597.

10. Chen K, Yeh P, Hsu C, Hsu C, Lu Y, Hsieh H et al. Bortezomib overcomes tumor necrosis factor-related apoptosis-inducing ligand resistance in hepatocellular carcinoma cells in part through the inhibition of the phosphatidylinositol 3-kinase/Akt pathway. J Biol Chem 2009; 284: 11121-11133.

11. Sun W, Nelson D, Alberts SR, Poordad F, Leong S, Teitelbaum UR et al. Phase lb study of mapatumumab in combination with sorafenib in patients with advanced hepatocellula carcinoma (HCC) and chronic viral hepatitis. J Clin Oncol 2011; 29 (Suppl 4) abstract 261.

12. MacFarlane M, Kohlhaas SL, Sutcliffe MJ, Dyer MJS, Cohen GM. TRAIL receptor-selective mutants signal to apoptosis via TRAIL-R1 in primary lymphoid malignancies. Cancer Res 2005; 65: 11265-11270.

13. van der Sloot AM, Tur V, Szegezdi E, Mullally MM, Cool RH, Samali A et al. Designed tumor necrosis factor-related apoptosis-inducing ligand variants initiating apoptosis exclusively via the DR5 receptor. Proc Natl Acad Sci USA 2006; 103: 8634-8639.

14. ten Cate B, Bremer E, de Bruyn M, Bijma T, Samplonius D, Schwemmlein M et al. A nove AML-selective TRAIL fusion protein that is superior to Gemtuzumab Ozogamicin in terms of in vitro selectivity, activity and stability. Leukemia 2009; 23: 1389-1397.

15. Lawrence D, Shahrokh Z, Marsters S, Achilles K, Shih D, Mounho B et al. Differentia hepatocyte toxicity of recombinant Apo2L/TRAIL versions. Nat Med 2001; 7: 383-385.

16. Schneider B, Münkel S, Krippner-Heidenreich A, Grunwald I, Wels WS, Wajant H et al. Potent antitumoral activity of TRAIL through generation of tumor-targeted single-chain fusion proteins. Cell Death Dis 2010; 1: e68.

17. Olayioye MA, Neve RM, Lane HA, Hynes NE. The ErbB signaling network: recepto heterodimerization in development and cancer. EMBO J 2000; 19: 3159-3167.

18. Naramura M, Gillies SD, Mendelsohn J, Reisfeld RA, Mueller BM. Therapeutic potential of chimeric and murine anti-(epidermal growth factor receptor) antibodies in a metastasis model for human melanoma. Cancer Immunol Immunother 1993; 37: 343-349.

19. $\mathrm{Ng} \mathrm{M}$, Cunningham D. Cetuximab (Erbitux)-an emerging targeted therapy for epidermal growth factor receptor-expressing tumours. Int J Clin Pract 2004; 58: 970-976.

20. Doody JF, Wang Y, Patel SN, Joynes C, Lee SP, Gerlak J et al. Inhibitory activity of cetuximab on epidermal growth factor receptor mutations in non small cell lung cancers. Mol Cancer Ther 2007; 6: 2642-2651.

21. Wajant H, Moosmayer D, Wüest T, Bartke T, Gerlach E, Schönherr U et al. Differentia activation of TRAIL-R1 and -2 by soluble and membrane TRAIL allows selective surface antigen-directed activation of TRAIL-R2 by a soluble TRAIL derivative. Oncogene 2001; 20: $4101-4106$

22. Berg D, Stühmer $T$, Siegmund $D$, Müller N, Giner $T$, Dittrich-Breiholz 0 et at Oligomerized tumor necrosis factor-related apoptosis inducing ligand strongly induces cell death in myeloma cells, but also activates proinflammatory signaling pathways. FEBS J 2009; 276: 6912-6927.

23. Holliger P, Prospero T, Winter G. Diabodies": small bivalent and bispecific antibody fragments. Proc Natl Acad Sci USA 1993; 90: 6444-6448.

24. Fan Z, Lu Y, Wu X, Mendelsohn J. Antibody-induced epidermal growth factor receptor dimerization mediates inhibition of autocrine proliferation of A431 squamous carcinoma cells. J Biol Chem 1994; 269: 27595-27602.

25. Krippner-Heidenreich A, Grunwald I, Zimmermann G, Kühnle M, Gerspach J, Sterns T et al. Single-chain TNF, a TNF derivative with enhanced stability and antitumoral activity. $\mathrm{J}$ Immunol 2008; 180: 8176-8183.

26. Gerspach J, Wajant H, Pfizenmaier K. Death ligands designed to kill: development and application of targeted cancer therapeutics based on proapoptotic TNF family ligands. Results Probl Cell Differ 2009; 49: 241-273.

27. Bremer E, Kuijlen J, Samplonius D, Walczak H, de Leij L, Helfrich W. Target cell-restricted and -enhanced apoptosis induction by a scFv:sTRAIL fusion protein with specificity for the pancarcinoma-associated antigen EGP2. Int J Cancer 2004; 109: 281-290.

28. Bremer E, Samplonius DF, Peipp M, van Genne L, Kroesen B, Fey GH et al. Target cellrestricted apoptosis induction of acute leukemic $T$ cells by a recombinant tumor necrosis factor-related apoptosis-inducing ligand fusion protein with specificity for human CD7. Cancer Res 2005; 65: 3380-3388.

29. Wajant H, Gerspach J, Pfizenmaier K. Engineering death receptor ligands for cancer therapy. Cancer Lett 2011; e-pub ahead of print 13 January 2011; doi:10.1016/ j.canlet.2010.12.019.

30. Schneider P, Holler N, Bodmer لا L, Hahne M, Frei K, Fontana A et al Conversion of membrane-bound Fas(CD95) ligand to its soluble form is associated with downregulation of its proapoptotic activity and loss of liver toxicity. J Exp Med 1998; 187: 1205-1213.

31. Koschny R, Walczak H, Ganten TM. The promise of TRAIL-potential and risks of a novel anticancer therapy. J Mol Med 2007; 85: 923-935.

32. Ashkenazi A. Targeting death and decoy receptors of the tumour-necrosis factor superfamily. Nat Rev Cancer 2002; 2: 420-430.

33. Song JH, Tse MCL, Bellail A, Phuphanich S, Khuri F, Kneteman NM et al. Lipid rafts and nonrafts mediate tumor necrosis factor related apoptosis-inducing ligand induced apoptotic and nonapoptotic signals in non small cell lung carcinoma cells. Cancer Res 2007; 67: 6946-6955

34. Psahoulia FH, Drosopoulos KG, Doubravska L, Andera L, Pintzas A. Quercetin enhances TRAIL-mediated apoptosis in colon cancer cells by inducing the accumulation of death receptors in lipid rafts. Mol Cancer Ther 2007; 6: 2591-2599.

35. Jo M, Kim TH, Seol DW, Esplen JE, Dorko K, Billiar TR et al. Apoptosis induced in normal human hepatocytes by tumor necrosis factor-related apoptosis-inducing ligand. Nat Med 2000; 6: 564-567.

36. Ganten TM, Koschny R, Sykora J, Schulze-Bergkamen H, Büchler P, Haas TL et al. Preclinical differentiation between apparently safe and potentially hepatotoxic applications of TRAIL either alone or in combination with chemotherapeutic drugs. Clin Cancer Res 2006; 12: 2640-2646.

37. Koschny R, Holland H, Sykora J, Haas TL, Sprick MR, Ganten TM et al. Bortezomib sensitizes primary human astrocytoma cells of WHO grades I to IV for tumor necrosis factor-related apoptosis-inducing ligand-induced apoptosis. Clin Cancer Res 2007; 13: 3403-3412.

38. Nussler AK, Nussler NC, Merk V, Brulport M, Schormann W, Hengstler JG. The Holy grail of hepatocyte culturing and therapeutic use. In: Santin M (ed). Regenerative Medicine Today. Springer International: Berlin, Germany, 2009, pp: 283-320.

39. Hopp J, Hornig N, Zettlitz KA, Schwarz A, Fuss N, Müller D et al. The effects of affinity and valency of an albumin-binding domain (ABD) on the half-life of a single-chain diabody-ABD fusion protein. Protein Eng Des Sel 2010; 23: 827-834.

40. Benedict CA, MacKrell AJ, Anderson WF. Determination of the binding affinity of an antiCD34 single-chain antibody using a novel, flow cytometry based assay. J Immunol Methods 1997; 201: 223-231.

41. Wüest T, Gerlach E, Banerjee D, Gerspach J, Moosmayer D, Pfizenmaier K. TNFSelectokine: a novel prodrug generated for tumor targeting and site-specific activation of tumor necrosis factor. Oncogene 2002; 21: 4257-4265.

42. Seidel N, Volkmann X, Länger F, Flemming P, Manns MP, Schulze-Osthoff K et al. The extent of liver steatosis in chronic hepatitis $\mathrm{C}$ virus infection is mirrored by caspase activity in serum. Hepatology 2005; 42: 113-120.

43. Kim TH, Youn YS, Jiang HH, Lee S, Chen X, Lee KC. PEGylated TNF-related apoptosisinducing ligand (TRAIL) analogues: pharmacokinetics and antitumor effects. Bioconjug Chem 2011; 22: 1631-1637.

Cell Death and Disease is an open-access journal published by Nature Publishing Group. This work is licensed under the Creative Commons Attribution-Noncommercial-No Derivative Works 3.0 Unported License. To view a copy of this license, visit http://creativecommons.org/licenses/by-nc-nd/3.0/

Supplementary Information accompanies the paper on Cell Death and Disease website (http://www.nature.com/cddis) 